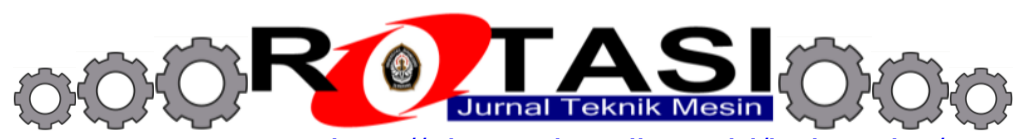

Available online at Website http://ejournal.undip.ac.id/index.php/rotasi

\title{
PENGAMATAN STRUKTUR MIKRO DAN KEKERASAN PADA RODA GIGI PASCA PENGERASAN PERMUKAAN MENGGUNAKAN PEMANAS INDUKSI
}

\author{
*Rifky Ismail, Nizar Rahman Aprilitama dan Sugiyanto \\ Jurusan Teknik Mesin, Fakultas Teknik, Universitas Diponegoro \\ J1. Prof. Sudharto, SH., Tembalang-Semarang 50275, Telp. +62247460059 \\ *E-mail: r_ismail@undip.ac.id
}

\begin{abstract}
ABSTRAK
Pemanasan induksi merupakan proses pemanasan benda kerja menggunakan metode induksi elektromagnetik. Arus eddy yang dihasilkan dalam logam menyebabkan pemanasan pada logam. Pemanas induksi dapat digunakan dalam berbagai fungsi, antara lain pengerasan permukaan, peleburan logam, pengelasan, dan pemanasan pada temperatur yang diinginkan. Pada industri otomotif, dibutuhkan pengerasan pada permukaan beberapa komponen seperti roda gigi, katup dan cranksaft dengan tetap menjaga keuletan di bagian dalam komponen tersebut. Objek pada penelitian ini adalah roda gigi transmisi yang membutuhkan tahan aus dann sifat keras pada permukaan serta tangguh dan ulet di bagian dalam. Proses pengerasan permukaan dilakukan menggunakan alat pemanas induksi. Material yang digunakan adalah baja AISI 4140 dan baja ST60 yang banyak digunakan sebagai bahan baku dalam industri alat transportasi. Spesimen berbentuk gear ditempatkan di tengah koil induksi dan dipanaskan sampai suhu austenit kemudian dicelupkan ke dalam minyak pendingin dengan cepat. Percobaan terhadap 12 spesimen dibedakan oleh variasi modul roda gigi induksi, serta temperatur dan waktu penahanan. Spesimen dianalisis dengan uji komposisi kimia, uji kekerasan makro dan uji mikrografi. Hasilnya adalah peningkatan nilai kekerasan permukaan dan ketebalan pengerasan permukaan. Semakin rendah frekuensi induksi maka pengerasan yang terjadi semakin tebal dan struktur martensit semakin dominan. Alat pemanas induksi terbukti mampu meningkatkan nilai kekerasan permukaan spesimen sebesar 65 - 75 HRC dengan ketebalan 3-4 mm sesuai yang distandarkan oleh ASM.
\end{abstract}

Kata Kunci: pemanas induksi, pengerasan permukaan roda gigi, struktur mikro dan kekerasan.

\section{PENDAHULUAN}

Roda gigi merupakan salah satu jenis transmisi daya yang paling banyak digunakan. Roda gigi memiliki kemampuan mentransmisikkan daya besar dan putaran yang cepat, serta mampu menaikkan dan menurunkan putaran secara kontinyu. Beberapa industri kecil dan menengah (IKM) di beberapa sentra industri logam Jawa Tengah sudah mampu memproduksi roda gigi. Salah satunya adalah CV. Mulya Jaya Agung IKM logam dan permesinan di kota Tegal yang memproduksi roda gigi. Prosen produksi CV Mulya Jaya Agung produksi roda gigi dilakukan dengan proses permesinan atau (machining) dan pengecoran (casting) seperti yang ditunjukkan pada Gambar 1.

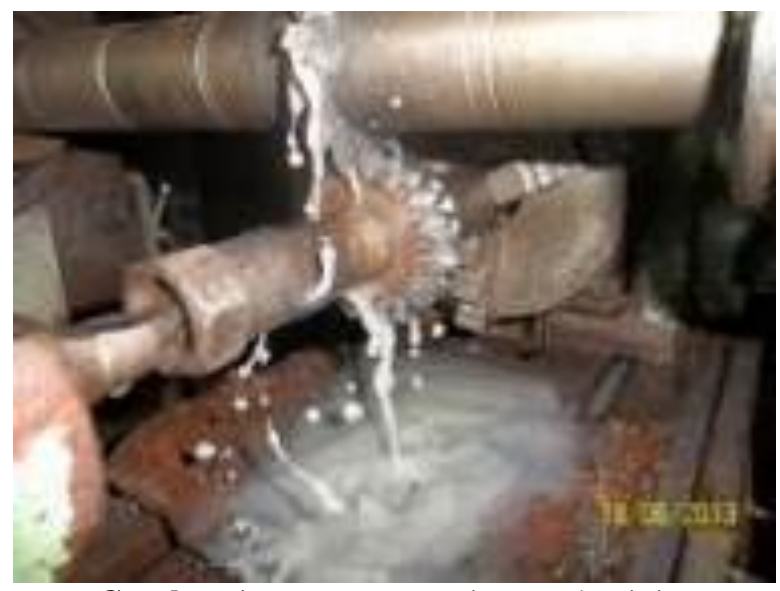

Gambar 1. Proses permesinan roda gigi

Perlakuan panas yang baik untuk roda gigi dan pin kereta adalah dengan surface hardening. Pada proses surface hardening, pemanasan hanya dilakukan pada permukaan saja. Ketebalan pengerasan dapat ditentukan dengan cara mengatur ketebalan pemanasan. Salah satu metode surface hardening yang dapat diterapkan untuk meningkatkan kekerasan bahan adalah induksi magnetik. Induksi magnetik ialah proses elektromagnetik nonkontak dimana logam 
yang akan dikeraskan diletakkan di dalam sebuah kumparan tembaga yang dialiri arus bolak balik frekuensi tinggi [1]. Pada penelitian ini, penulis fokus untuk membahas metode Induction Hardening (pengerasan induksi). Pengerasan induksi ialah proses elektro magnetik non strip kontak dimana logam yang akan dikeraskan diletakkan didalam sebuah kumparan tembaga yang dialiri arus bolak-balik arus frekuensi tinggi [2].Adapun tujuan dari penelitian ini adalah: Pertama melakukan proses pengerasan permukaan menggunakan pemanas induksi pada roda gigi. Dan kedua mengamati pengaruh pengerasan permukaan (Quenching) pada roda gigi dengan variasi modul terhadap struktur mikro dan kekerasannya.

\section{METODE PENELITIAN \\ 2.1 Diagram Alir Penelitian}

Menentukan topic bertujuan untuk menentukan tema dan pokok pikiran yang menjadi dasar penelitian.Melakukan studi pustaka bertujuan untuk mendapatkan literatur maupun referensi yang dapat menguatkan penelitian yang kami laksanakan. Materinya adalah studi tentang pemanasan induksi, quenching hardening dengan mesin pemanas induksi, pengerasan permukaan, analisa penyeebaran nilai kekerasan, dan struktur mikro. Penyiapan specimen yang digunakan pada penelitian adalah spesimen roda gigi ST 60 dan AISI 4140 yang merupakan raw material dari roda gigi produk IKM Tegal. Melakukan proses bubut dari material ST 60 dan AISI 4140, kemudian mengukur dimensi yang disesuaikan untuk diuji induksi. Material yang didapat kemudian dibentuk roda gigi sesuai dengan modul untuk pengujian. Pembuatan elemen pemanas induksi Elemen pemanas induksi dibuat dari pipa dan selang tembaga yang disambung dan dibentuk lilitan sesuai dengan geometri dari spesimen. Lilitan selang tembaga dibungkus isolator asbes untuk mencegah hubungan arus pendek jika terjadi persentuhan dengan spesimen atau antar lilitan yang dijelaskan seperti pada Gambar 2 digram alir penelitian.

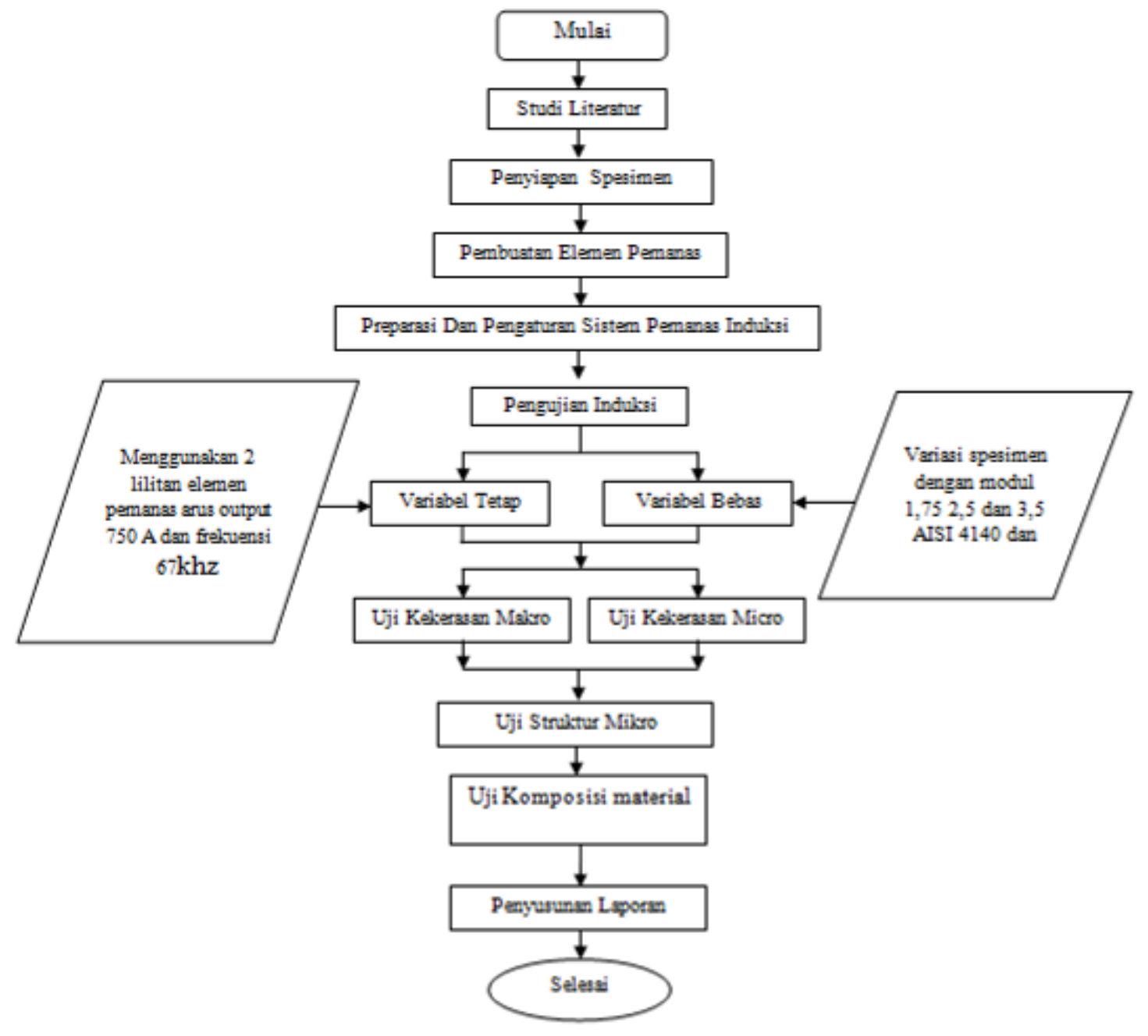

Gambar 2. Diagram alir penelitian.

Preparasi dan pengaturan alat pengujian induksi.Satu set mesin pemanas induksi disusun bersama seperangkat alat pendukung dan alat ukur data pengujian. Spesimen diposisikan di tengah-tengah elemen pemanas induksi dengan gap dimensi tertentu. Pengujian pemanasan induksi.Proses pemanasan induksi dilaksanakan dalam orde waktu sekian 
detik hingga temperatur spesimen mencapai suhu austenit baja ST 60 dan AISI 4140. Setelah permukaan tepi spesimen memasuki suhu austenit dilakukan pendinginan cepat dengan menjatuhkan spesimen pada kaleng berisi oli pendingin khusus quenching.Pengujian komposisi kimia melakukan uji kandungan yang ada pada logam tersebut untuk mengetahui komponen kimia utama dan penyusun, serta persentase dari paduan yang ada pada logam tersebut. Pengujian kekerasan dilakukan untuk mengukur titik-titik persebaran nilai kekerasan dari tepi permukaan hingga tengah dan membandingkan nilai kekerasan logam sebelum diinduksi dan setelah di-quench hardening. Pengujian mikrografi dilakukan untuk membandingkan perubahan struktur mikro akibat pengerasan permukaan dengan mesin induksi dan menganalisa pengaruh perbedaan nilai kekerasan terhadap struktur mikro. Pengolahan data dan analisa dari data hasil pengujain yang dilakukan diolah serta dianalisa berdasarkan dasar teori yang diperoleh dari studi literatur. Kesimpulan menyimpulkan hasil analisa tentang parameter pemanasan induksi, uji kekerasan dan mikrografi logam baja ST 60 dan AISI 4140 setelah diberi perlakuan panas oleh mesin pemanas induksi

\subsection{Bahan Uji}

Bahan yang digunakan dalam penelitian ini adalah spesimen baja ST 60.

Spesimen memiliki dimensi dengan diameter mengacu pada diameter roda gigi, yang ditunjukkan pada Gambar 3 yaitu sebagai berikut [3]:

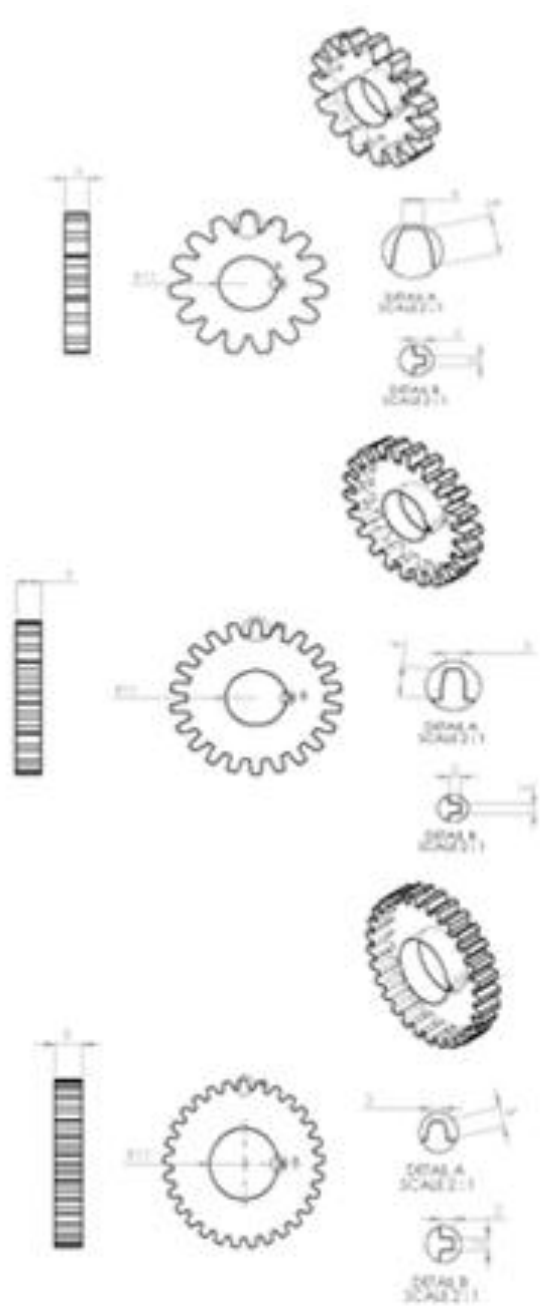

(a)

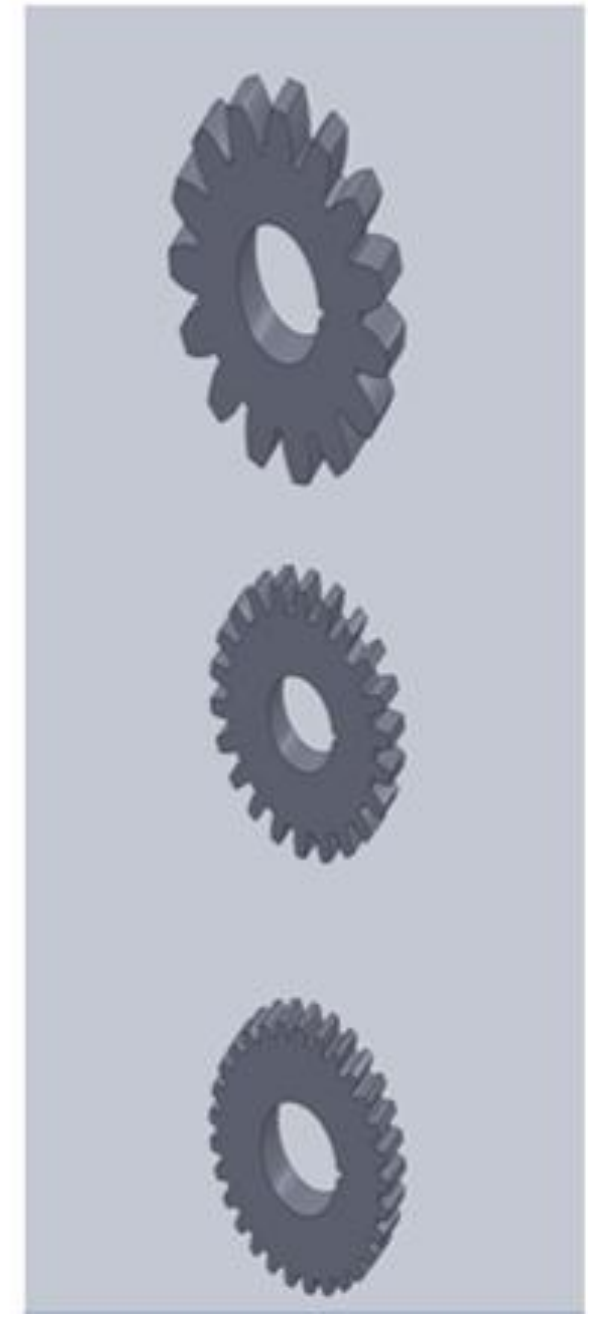

(b)

Gambar 3. (a) Dimensi roda gigi buatan IKM sebagai acuan, (b) bentuk dan dimensi spesimen.

\subsection{Alat Pengujian Pemanas Induksi}

Instalasi umum alat pengujian pemanas induksi untuk pengerasan permukaan yang digunakan dalam penelitian dapat dilihat pada Gambar 4 di bawah ini [4]. 


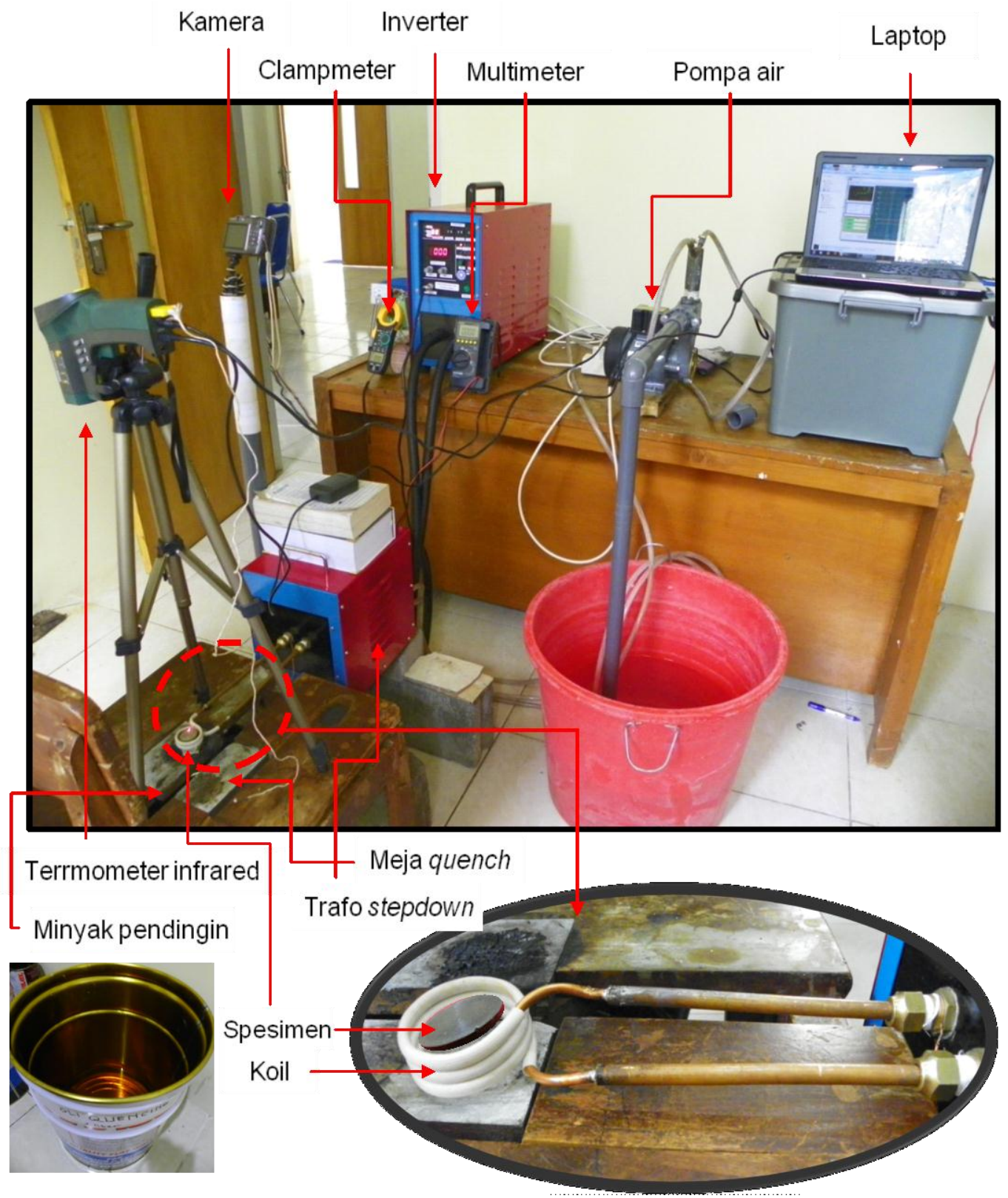

Gambar 4. General layout alat pemanas induksi.

\subsection{Uji Kekerasan Rockwell}

Pengujian kekerasan ini dilakukan untuk mengetahui perilaku sifat mekanik (kekerasan material) setelah diberi perlakuan panas induksi baik quenching maupun tempering.

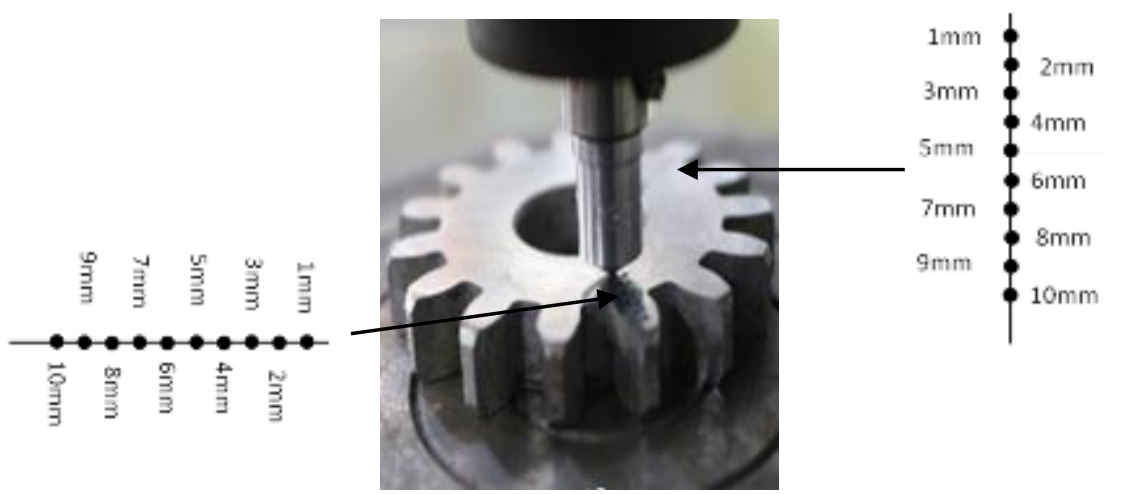

Gambar 5. Posisi, jarak, dan arah pengujian kekerasan. 


\section{HASIL DAN PEMBAHASAN}

\subsection{Hasil Pengujian}

Pengujian komposisi kimia dilakukan di Laboratorium Logam PT Putra Bungsu Makmur, Tarub, Tegal dengan menggunakan emission spectrometer. Pengujian ini bertujuan untuk mengetahui kandungan / komposisi kimia yang terkandung dalam spesimen ST 60 dan AISI 4140. Tabel 1 berikut menunjukkan hasil pengujian komposisi untuk spesimen ST 60 dan AISI 4140.

Tabel 1. Komposisi Unsur pada Spesimen AISI 4140 dan ST 60.

\begin{tabular}{|c|c|c|c|}
\hline No & Unsur & $\begin{array}{c}\text { Pessentast kandungan (\%) } \\
\text { peds AISI } 4140\end{array}$ & $\begin{array}{c}\text { Perientase kandusgan (\%6) } \\
\text { pede ST 60 }\end{array}$ \\
\hline 1 & $\mathrm{Fe}$ & 96,74612 & 98,10659 \\
\hline 2 & $\mathrm{C}$ & 0,35883 & 0,46394 \\
\hline 3 & $\mathrm{Mn}$ & 0,79237 & 0,70267 \\
\hline 4 & $\mathrm{Si}$ & 0,37152 & 0,24037 \\
\hline 5 & $\mathrm{P}$ & 0,01347 & 0,02213 \\
\hline 6 & $\mathrm{~S}$ & 0,04121 & 0,00472 \\
\hline 7 & $\mathrm{Ni}$ & 0,15206 & 0,00847 \\
\hline 8 & $\mathrm{Cr}$ & 1,08606 & 0,35669 \\
\hline 9 & $\mathrm{Cu}$ & 0,16734 & 0,02643 \\
\hline 10 & $\mathrm{Mo}$ & 0,20656 & 0,00169 \\
\hline 11 & $\mathrm{~V}$ & 0,00818 & 0,00226 \\
\hline 12 & $\mathrm{Ti}$ & 0,0062 & 0,00442 \\
\hline
\end{tabular}

\begin{tabular}{|c|c|c|c|}
\hline No. & Unaur & $\begin{array}{c}\text { Dartantnos kandismgan (*G) } \\
\text { pada AISI } 4140\end{array}$ & $\begin{array}{c}\text { Dartantata kandungern } \\
\text { ("h) pada } \$ T \text { SD }\end{array}$ \\
\hline 13 & Al & 0,01223 & 0,01679 \\
\hline 14 & $\mathrm{Nb}$ & $-0,00104$ & $-0,00274$ \\
\hline 15 & $\mathrm{w}$ & 0,00049 & 0,00259 \\
\hline 16 & An & 0,00757 & 0,01493 \\
\hline 17 & $8 n$ & 0,01398 & 0,00141 \\
\hline 18 & $\mathrm{Co}$ & 0,00798 & 0,00504 \\
\hline 19 & $\mathrm{Fb}$ & 0,00415 & 0,00757 \\
\hline 20 & $\mathbf{B}$ & 0,00008 & 0,00051 \\
\hline 21 & sh & 0,00332 & 0,002224 \\
\hline 22 & $\mathbf{B}_{4}$ & 0,00713 & 0,00435 \\
\hline 23 & Ca & 0,00232 & 0,00075 \\
\hline 24 & $\mathrm{ME}$ & 0,00112 & 0,00003 \\
\hline 25 & $Z n$ & 0,00093 & 0,00074 \\
\hline 26 & C. & 0,37706 & 0,47289 \\
\hline 27 & $\mathbb{N}$ & 0,00721 & 0,00491 \\
\hline
\end{tabular}

\subsection{Melakukan Pengerasan Permukaan (Quenching)}

Quenching dengan alat pemanas induksi bertujuan untuk meningkatkan kekerasan permukaan spesimen roda gigi Baja AISI 4140 dan ST 60. Proses pengujiannya dilakukan dengan memanaskan permukaan spesimen hingga suhu austenit selama kurang lebih 9-13 detik kemudian dicelup cepat ke dalam cairan pendingin hingga terjadi perubahan fasa baja dari austenit menjadi martensit, dimana struktur lunak berubah menjadi sangat keras.

Tabel 2. Hasil pengujian kekerasan setelah induction quenching

\begin{tabular}{|c|c|c|c|c|c|c|}
\hline \multirow{4}{*}{$\begin{array}{l}\text { Posisi } \\
\text { dasi } \\
\text { tepi } \\
\text { (muri) }\end{array}$} & \multicolumn{6}{|c|}{ Nilai kelierasan (HRC) } \\
\hline & $\begin{array}{l}\text { sebehum } \\
\text { petiakuam }\end{array}$ & $\begin{array}{l}\text { sebelum } \\
\text { perlakuan }\end{array}$ & $\begin{array}{l}\text { sebehum } \\
\text { pedaktumen }\end{array}$ & $\begin{array}{c}\text { Setelah } \\
\text { perlakumen }\end{array}$ & $\begin{array}{c}\text { Setelah } \\
\text { petlakuan }\end{array}$ & $\begin{array}{c}\text { Setelah } \\
\text { pectakuan }\end{array}$ \\
\hline & ST 60 & 5T 60 & ST 60 & ST 60 & ST 60 & ST 60 \\
\hline & $\begin{array}{l}\text { Modul } \\
1,75\end{array}$ & $\begin{array}{l}\text { Modul } \\
2,5\end{array}$ & $\begin{array}{c}\text { Modul } \\
3.5\end{array}$ & $\begin{array}{c}\text { Modul } \\
1,75\end{array}$ & $\begin{array}{c}\text { Modul } \\
2.5\end{array}$ & $\begin{array}{c}\text { Modul } \\
3,5\end{array}$ \\
\hline 1 & 18 & 17 & 18.5 & 55 & 56,5 & 55 \\
\hline 2 & 18 & 17 & 18 & 48 & 54,5 & 54 \\
\hline 3 & 17 & 17 & 1 ? & 36,4 & 58 & 53 \\
\hline 4 & 17,5 & 16.5 & 17 & 24,5 & 58 & 51 \\
\hline 5 & 16,5 & 16,5 & 16,5 & 16,5 & 59 & 29,5 \\
\hline 6 & 16 & 16 & 16 & 16 & 50,5 & 22,5 \\
\hline 7 & 15 & 16 & 16 & 16 & 44 & 18,5 \\
\hline 8 & 15 & 15,5 & 15,5 & 16 & 37 & 18 \\
\hline 9 & 14 & 15 & 15 & 16,5 & 33 & 16 \\
\hline 10 & 14 & 15 & 15 & 16,5 & 29 & 14 \\
\hline 11 & 13 & 16.5 & 15 & 14 & 14,5 & 15 \\
\hline 12 & 13 & 14 & 15 & 14 & 14 & 15 \\
\hline 13 & 12 & 14 & 15 & 13 & 14 & 15 \\
\hline 14 & 12 & 13 & 14 & 13 & 13 & 14 \\
\hline 15 & 12 & 13 & 14 & 13 & 13 & 14 \\
\hline
\end{tabular}

\begin{tabular}{|c|c|c|c|c|c|c|}
\hline \multirow{6}{*}{$\begin{array}{c}\text { Posisi } \\
\text { dari } \\
\text { tepi } \\
\text { (trub) }\end{array}$} & \multicolumn{6}{|c|}{ Silai kekerasan (HIRC) } \\
\hline & $\begin{array}{l}\text { sebolium } \\
\text { periakumem }\end{array}$ & $\begin{array}{l}\text { sebidum } \\
\text { perlakumm }\end{array}$ & $\begin{array}{l}\text { sobihum } \\
\text { perlakumen }\end{array}$ & $\begin{array}{l}\text { satalah } \\
\text { periakimem }\end{array}$ & $\begin{array}{c}\text { sotelah } \\
\text { perlakumm }\end{array}$ & $\begin{array}{l}\text { setelah } \\
\text { perlakumm }\end{array}$ \\
\hline & AISI & AISI & AISI & AISI & AISI & AISI \\
\hline & 4140 & 4140 & 4140 & 4140 & 4140 & 4140 \\
\hline & Modal & Modal & Modal & Modtul & Medtul & Modnl \\
\hline & 1,75 & 2,5 & 3,5 & 1,75 & 2,5 & 3,5 \\
\hline 1 & 33 & 37,5 & 34,5 & 67 & 75 & 68 \\
\hline 2 & 32 & 36 & 34 & so & 65 & 67 \\
\hline 3 & 31,5 & 36 & 34 & 40.5 & 64.5 & 56 \\
\hline 4 & 31.5 & 35 & 33 & 47.5 & 64 & 64 \\
\hline 5 & 31 & 34 & 30,5 & 45 & 54 & 63 \\
\hline 6 & 31 & 34 & 30,5 & 42 & 52 & 63 \\
\hline 7 & 30,5 & 33 & 30 & 40 & $\$ 1$ & 60 \\
\hline 8 & 30 & 32 & 28,5 & 34 & 50 & 59 \\
\hline 9 & 28,5 & 31,5 & 28 & 33 & 49 & 57 \\
\hline 10 & 28 & 31 & 26 & 33 & 48 & 42 \\
\hline 11 & 26 & 31 & 25 & 32 & 45 & 39 \\
\hline 12 & 24 & 30 & 25 & 32 & 35 & 34 \\
\hline 13 & 24 & 30 & 25 & 32 & 53,5 & 34 \\
\hline 14 & 23 & so & 23 & so & 33 & 35 \\
\hline 15 & 22 & 30 & 22.5 & 30 & 33 & 33 \\
\hline
\end{tabular}


Dari data kekerasan setelah induction quenching di atas terdapat beberapa fenomena pengerasan permukaan yang dapat dilihat pada plot data berikut ini.

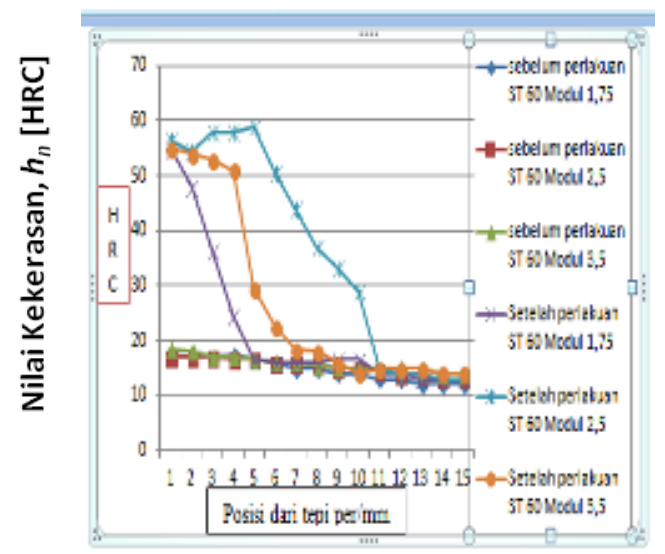

(a)

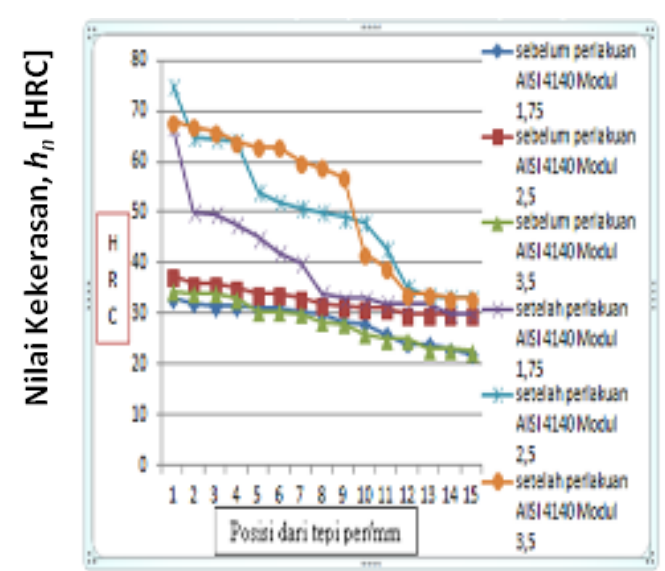

(b)

Gambar 6. Fenomena pengerasan permukaan induksi quenching (a) hasil roda gigi ST 60 dan (b) hasil roda gigi AISI 4140

\subsection{Melakukan Uji Kekerasan Micro Vickers}

Untuk mengetahui nilai kekerasan pada spesimen penelitian ini, dilakukan uji kekerasan mikro Vickers yang dilakukan di Laboratorium UPT terpadu UNDIP Semarang. Pengujian menggunakan 12 spesimen. Spesimen AISI 4140 (3 tanpa perlakuan dan 3 perlakuan induksi) dan ST 60 (3 tanpa perlakuan dan perlakuan induksi). Pada spesimen pertama pengambilan titik pengujian sebanyak tiga titik dilakukan secara berurutan dari titik yang terkena induksi, titik transisi induksi, dan titik tidak terkena dampak induksi. pengambilan titik pengujian dengan jarak 500 micron - 1500 micron, 6000 micron - 7500 micron dan 1300 micron - 1500 micron. Titik pertama dimulai dari tepi / tooth roda gigi, lalu bagian tengah (bagian transisi) kemudian yang terakhir bagian dalam tidak terkena induksi Nilai kekerasan HV didapat dari rumus (1) yaitu:

$\mathrm{HV}=\frac{2000 \mathrm{P} \sin (\propto / 2)}{\mathrm{d}^{2}}=\frac{1854,4 \mathrm{P}}{\mathrm{d}^{2}}$

Keterangan:

$\mathrm{d} \quad=$ rata-rata diagonal setelah penetrasi $(\mu \mathrm{m})$

$\alpha=$ sudut permukaan, yang sudah ditetapkan sebesar $136^{0}$

$\mathrm{P} \quad=$ beban yang diberikan pada saat penetrasi

Pengujian mikro Vickers pada penelitian ini menggunakan pembebanan sebesar 200 gf dengan waktu pembebanan selama 10 detik. Hasil pengujian kekerasan Micro Vickers untuk spesimen Baja ST 60 dan AISI 4140 sebelum dan setelah perlakuan induksi dan quenching dibawah kemudian masing-masing dibuat kurva antara nilai kekerasan, $\mathrm{h}_{\mathrm{n}}$ dan posisi dari tepi, $\mathrm{x}$, seperti hasil yang terlihat dalam Gambar 3 berikut ini:

Tabel 3. Hasil pengujian kekerasan setelah induction tempering.

\begin{tabular}{|c|c|c|c|c|c|c|}
\hline \multirow{3}{*}{$\begin{array}{c}\text { Posia } \\
\text { caritepi } \\
\text { (Micron) }\end{array}$} & \multicolumn{6}{|c|}{ Vilai kebrerasin rï mitco ricken (HRV) } \\
\hline & $\begin{array}{c}\text { stedire } \\
\text { pellakuan }\end{array}$ & $\begin{array}{l}\text { sebeim } \\
\text { perlakuar }\end{array}$ & \begin{tabular}{|l} 
sebulum \\
zelahtan
\end{tabular} & $\begin{array}{c}\text { Seteiah } \\
\text { priahan }\end{array}$ & $\begin{array}{c}\text { Seteliz } \\
\text { zerlahtan }\end{array}$ & $\begin{array}{c}\text { Strelah } \\
\text { perlakuan }\end{array}$ \\
\hline & $\begin{array}{c}\text { ST60 } \\
\text { Modd L, }\end{array}$ & $\begin{array}{c}\text { ST } 60 \\
\text { Modd2S, }\end{array}$ & $\begin{array}{c}\text { \$760 } \\
\text { Nojuld 3, }\end{array}$ & $\begin{array}{c}\text { 5T6. } \\
\text { Moذd 1,75 }\end{array}$ & \begin{tabular}{|c|} 
ST50 \\
Nodud2,
\end{tabular} & $\begin{array}{c}\text { ST60 } \\
\text { Modd } 35,5\end{array}$ \\
\hline 500 & 313,8 & 393,7 & $302:$ & 799,3 & 873,8 & 8983 \\
\hline 1002 & 274,6 & 3659 & 2779 & 856,1 & 8378 & 8611 \\
\hline 1502 & 205.1 & 3396 & 2889 & 889,6 & 696,2 & 7291 \\
\hline 8002 & 257,1 & 3555 & 267,8 & 826 & 3728 & 577 \\
\hline 6502 & 2422 & 3343 & 2623 & 678,2 & 298,3 & 383 \\
\hline 9002 & $195 ; 3$ & 349,3 & 280,8 & 42,7 & 294,6 & 3217 \\
\hline 1302 & 1928 & $34: 9$ & 259,2 & 299 & 276,2 & 245 \\
\hline 13500 & 185,2 & 3472 & 285 & 289 & $2: 9,5$ & 237 \\
\hline 14000 & 179,3 & 3313 & 278 & 272,1 & 265 & 41. \\
\hline
\end{tabular}

\begin{tabular}{|c|c|c|c|c|c|c|}
\hline \multirow{3}{*}{$\begin{array}{c}\text { Posis } \\
\text { dnnitepp } \\
\text { (Miszn) }\end{array}$} & \multicolumn{6}{|c|}{ Nilai kekerasan vji micno rickers (BRV) } \\
\hline & $\begin{array}{l}\text { sebelim } \\
\text { pellakana }\end{array}$ & \begin{tabular}{|c|c} 
sajetrm \\
pendaluax
\end{tabular} & $\begin{array}{c}\text { satettm } \\
\text { yendat:ax }\end{array}$ & $\begin{array}{c}\text { settlah } \\
\text { perlaknan }\end{array}$ & $\begin{array}{c}\text { settelah } \\
\text { perlahus! }\end{array}$ & $\begin{array}{c}\text { settlah } \\
\text { pendaluax }\end{array}$ \\
\hline & $\begin{array}{l}\text { AISL }+140 \\
\text { Notal 1,75 }\end{array}$ & $\begin{array}{l}\text { AISI 14140 } \\
\text { Madd 2:5 }\end{array}$ & 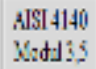 & $\begin{array}{l}\text { AIST } 1140 \\
\text { Nadd 1,75 }\end{array}$ & $\begin{array}{l}\text { AISI 4140 } \\
\text { Motul 2,5 }\end{array}$ & $\begin{array}{l}\text { AISI 4140 } \\
\text { Modil 3,3 }\end{array}$ \\
\hline 500 & 403,5 & 343 & 381,7 & 794,8 & 899,3 & 99,5 \\
\hline 1000 & 4643 & 350 & 374,2 & 782,4 & 916,1 & 789,3 \\
\hline $150 \%$ & 368,9 & 399,6 & 373,7 & 735,7 & 861,1 & 729,1 \\
\hline $6: 02$ & 308,4 & 301 & 34,5 & 621,7 & 656,8 & 375 \\
\hline 6500 & 324,3 & 366,1 & $39 i$ & 577 & 649,5 & 355 \\
\hline 700 & 329,3 & 384,5 & $3 \$ 3$ & 371 & 626,1 & 334 \\
\hline 1300 & 359,8 & 369,7 & 384,2 & 335,9 & 320,5 & 325,7 \\
\hline $13 \% 0$ & 329,1 & 363,5 & 351,2 & 320,3 & 322,2 & 303,2 \\
\hline $140: 0$ & 307,7 & 357,8 & 343,2 & 344,4 & 316,8 & 303,4 \\
\hline
\end{tabular}




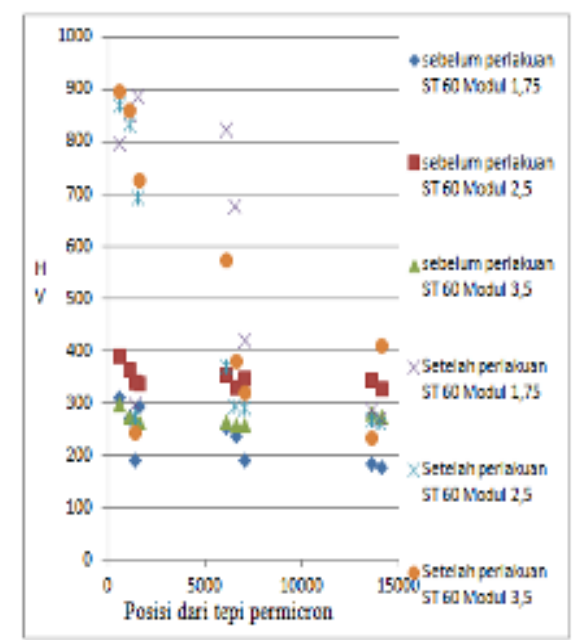

(a)

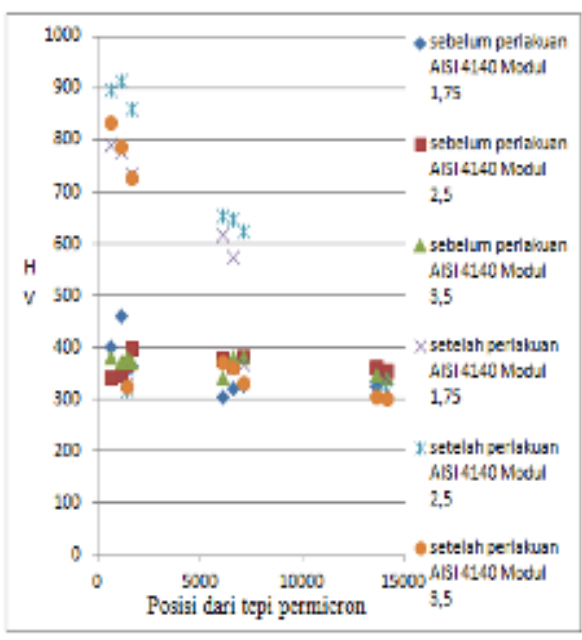

(b)

Gambar 7. Kurva nilai kekerasan micro vickers, $h_{\mathrm{n}}$ (a) roda gigi ST 60 (b) Baja AISI 4140 3 berikut ini.

Perlakuan yang diberikan pada tiap-tiap spesimen roda gigi Baja ST 60 dan AISI 4140 dapat diamati pada Tabel

Tabel 3. Parameter pengujian induksi untuk spesimen 11.

\begin{tabular}{|l|c|c|}
\hline \multirow{2}{*}{\multicolumn{1}{|c|}{ Parameter }} & \multicolumn{2}{c|}{ Kondisi parameter } \\
\cline { 2 - 3 } & Quenching & $8,7 \mathrm{~A}$ \\
\hline Arus input & $42,8 \mathrm{~A}$ & $40 / 20 \mathrm{detik}$ \\
\hline Waktu pemanasan / penahanan & $9 /-$ detik & $150 \mathrm{~A}$ \\
\hline Arus output & $738,3 \mathrm{~A}$ & $65 \mathrm{kHz}$ \\
\hline Frekuensi & $72,5 \mathrm{kHz}$ & $-1250^{\circ} \mathrm{C}$ \\
\hline Emisivitas IR/suhu temper & $0,73 /-$ & $265^{\circ} \mathrm{C}$ \\
\hline Suhu akhir terbaca IR & $678,8^{\circ} \mathrm{C}$ & $\mathrm{udara}$ \\
\hline Media pendingin & minyak & $50,0 \mathrm{HRC}$ \\
\hline Nilai kekerasan & $56,4 \mathrm{HRC}$ & \\
\hline
\end{tabular}

\subsection{Foto Makro Spesimen Uji}

Setelah dilakukan proses penyiapan spesimen yang meliputi pengamplasan (grinding), pemolesan (polishing), dan pengetsaan maka pada spesimen akan terlihat gradasi warna yang berbeda. Dengan gradasi warna ini kita secara kasat mata dapat melihat ketebalan pengerasan pada spesimen roda gigi, baik roda gigi AISI 4140 maupun ST 60 . Daerah yang lebih gelap menunjukkan bahwa daerah tersebut memiliki kekerasan yang lebih tingi dibandingkan daerah yang terang [5]. Berikut adalah hasil foto makro dari kedua spesimen:

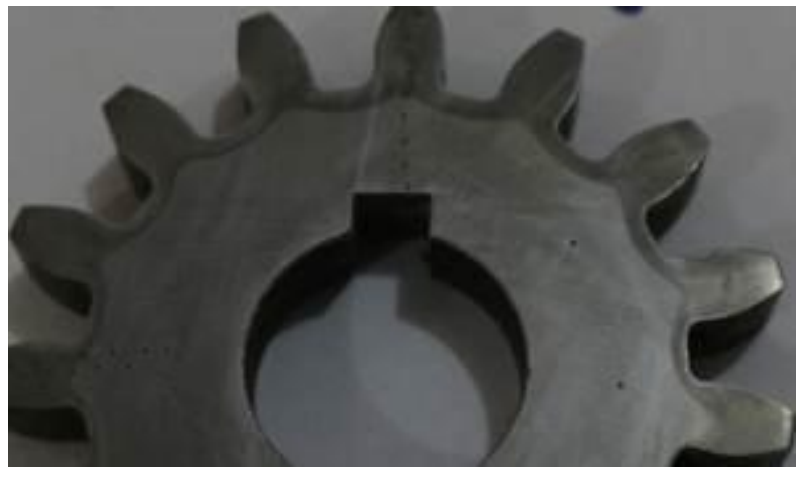

(a)

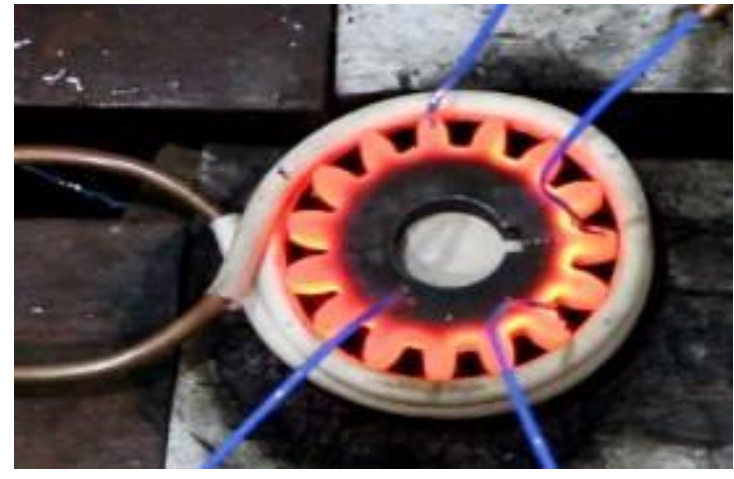

(b) 


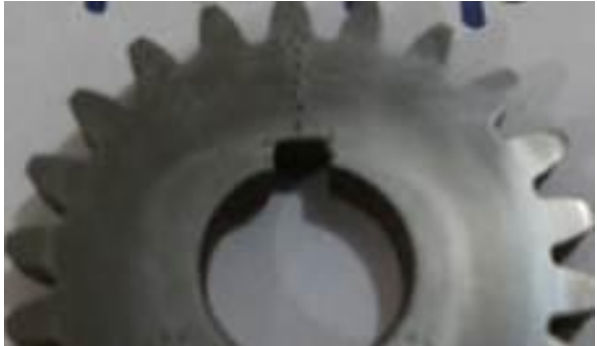

(c)

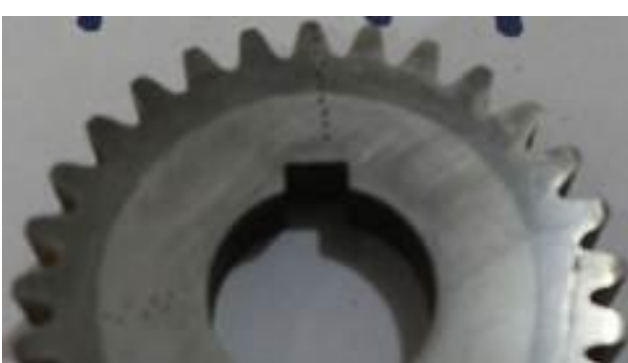

(d)

Gambar 8. Tahapan proses pemanasan induksi dan pengujian pada spesimen (a) saat akan dicelup cepat,

(b) setelah diuji kekerasan dan foto mikro hasil quench modul 3,5 (c) setelah diuji kekerasan dan foto mikro hasil quench modul 2,5, dan (d) setelah diuji kekerasan dan foto mikro hasil quench modul 1,75

\subsection{Foto Struktur Mikro}

Pengujian struktur mikro dilakukan dengan menggunakan optical microscope. Pengujian ini bertujuan untuk mengetahui evolusi mikrografi spesimen dari sebelum diberi perlakuan hingga dilakukan induction quenching (5).

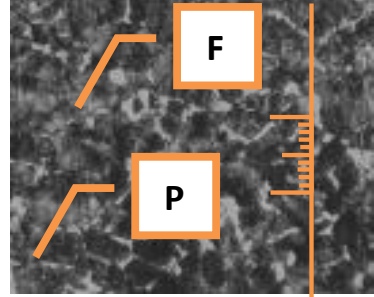

(a)

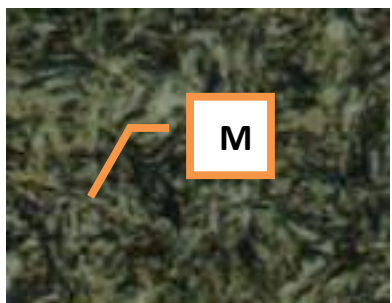

(d)

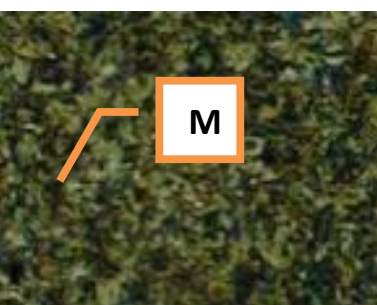

(b)

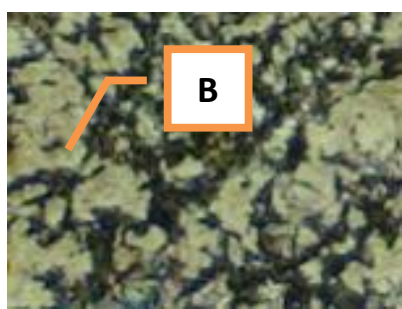

(c)

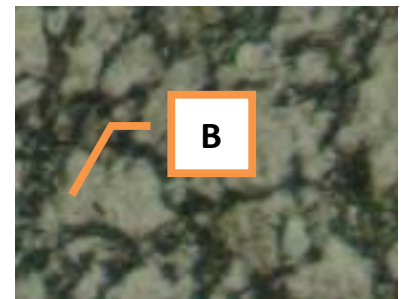

(e)

Keterangan:

[F] Ferrite

[P] Pearlite

[B] Baunite

[M] Martensitc

Gambar 9. Evolusi struktur mikro baja ST 60 (a) raw material sekeras 22 HRC perbesaran 100x, (b) dan (c) titik permukaan spesimen 3 yang mengalami pengerasan hingga 56,5 HRC setelah proses induction quench dengan perbesaran 100x, serta (d) dan (e) titik permukaan spesimen 3 yang mengalami peremajaan dengan nilai $50 \mathrm{HRC}$ setelah proses induction heating dengan perbesaran 200x.

\section{KESIMPULAN}

Berdasarkan hasil penelitian dan pengujian yang telah dilakukan dapat disimpulkan sebagai berikut:

1) Setelah dilakukan proses pengerasan permukaan menggunakan pemanas induksi pada roda gigi ST 60 dan AISI 4140 menghasilkan tingkat kekerasan permukaan yang bervariasi.

2) Hasil kekerasan macro hardness dan micro vickers menunjukkan 6 spesimen roda gigi ST 60 dan AISI 4140 setelah di induksi mengalami kenaikkan curva kekerasan permukaan dari sebelum perlakuan dan setelah perlakuan induksi, spesimen roda gigi ST 60 naik menjadi 3 kali lipat nilai kekerasannya sedangkan pada roda gigi AISI 4140 naik 2 kali lipat.

\section{REFERENSI}

[1] Callebaut J., 2007, Power Quality and Utilisation Guide, www.leonardo-energy.org.

[2] Rudnev V. I., Loveless D., Cook R., 2003, “Handbook of Induction Heating," Marcel Decker, Inc., New York.

[3] Davis J.R., Davis., 2005, Gear Materials, Properties, and Manufacture, ASM International

[4] Rudnev, V. I., Loveless D., Marshall B., 2000, Gear Heat Treatment by Induction, Madison Height, Michigan

[5] Haimbaugh R. E., 2001, "Practical Induction Heat Treating," ASM International, USA. 